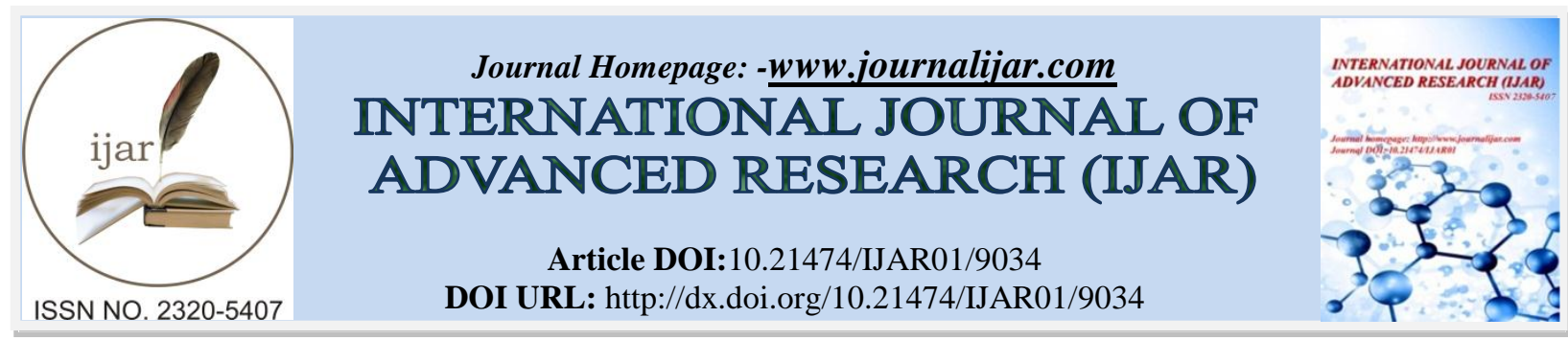

RESEARCH ARTICLE

\title{
THE EFFECT OF COGNITIVE CONFLICT LEARNING MODEL TOWARD VIII GRADE STUDENTS' CRITICAL THINKING SKILLS IN TERMS OF COGNITIVE STYLE IN BUKITTINGGI.
}

Sari Rahma Chandra And Ahmad Fauzan.

Mathematic Education, Universitas Negeri Padang And Prof. Dr Hamka Street Air Tawar Padang, West Sumatera.

\section{Manuscript Info}

\section{Manuscript History}

Received: 08 March 2019

Published: May 2019

\section{Key words:-}

critical thinking skills, Cognitive conflict

learning model, Cognitive styles, conventional learning model.
Final Accepted: 10 April 2019

\begin{abstract}
The aim of this research is to know the effect of cognitive conflict learning model in comparison with conventional learning model toward mathematical critical thinking skill in terms of cognitive styles. The research is conducted in three junior high schools in Bukittinggi by limiting only two classes for each school. The classes are divided into control and experimental class. This research uses quasi experiment with non-equivalent control posttest only group design. Hypotheses tests for this research are Mann-Whitney U test and T test. Based on the data analysis results, students' critical thinking skills that implemented the cognitive conflict learning model is better than conventional teaching.
\end{abstract}

Copy Right, IJAR, 2019,. All rights reserved.

\section{Introduction:-}

Mathematics is one of the main subjects in Indonesia National Exam where the students are expected to master it well. In order to achieve it, students need thinking abilities. There are 4 levels of thinking abilities. They are recall thinking, basic thinking, critical thinking and creative thinking. [1].

The high level of thinking is expected to be applied in as early as possible. So that, in the future, students are able to express their critical ideas. Critical thinking is also an essential skill in daily life aspects. Not only the students must possess critical thinking skills but also the teachers are mandatory to master it which regulated in national education laws.

In fact, the implementation of mathematics teaching and learning process in schools has not achieved the goal standard. The teaching and learning process does not engage the students in active learning, low comprehension and passive learners. Most of the students do not fully understand nor comprehend the lesson.

The research result, conducted by Mutia, states that the students got score in critical thinking ability in quadratic equation. Only 4 out of 28 students met the standard score. It means that $86 \%$ majority are failed. Which lead to the first conclusion, the grade VIII students' critical thinking ability are poor.

They should start with creating and explaining the mathematics model in the given questions. For example, The price of one eraser is equal to $x$ and the price of one sharperner is equal to $y$. Then, the students can proceed to mathematics model related to the math problem above. The students are not able to interpret the daily problem into mathematics problem nor fulfill one of the critical thinking skills, analyzing.

Corresponding Author:-Sari Rahma Chandra.

Address:-Mathematic Education, Universitas Negeri Padang AndProf.Dr Hamka Street Air Tawar 
The teaching and learning process in classroom is not able to create room for the students to develop themselves in critical thinking process. Most of them cannot understand simple math word problems which will be connected to concepts comprehension. The low critical thinking skill can be seen from solved problem and students' participation in teaching and learning process.

The variety of critical thinking skill and students' participation found in this case is caused by several factors involving students, teachers, classroom atmosphere, teaching tools and media. The prominent factors in low critical thinking skill and students' cognitive process in learning mathematics are 1) the teaching and learning process is teacher-centered. Teachers are too dominant in taking control all classroom activities. So, the students will rely on teachers provided information and become passive learners. 2) Low comprehension and study quality toward mathematics, it makes the students uninterested which lead to students' low critical thinking skill. 3) Tools and media are not provided for all the students. 4) The subject itself and math concepts are considered as difficult lesson.

Based on those facts discussed above, the writer concludes that the main problem why students have low critical thinking skill and poor class participation are the teachers and students themselves. For the students, the inner conflicts are low motivation, interest, will, and awareness to study. The outer are learning environment, family and friends. On the other hand, teachers need to find and implement the proper teaching strategy and learning model that help the students to understand the lesson easily.

Thus, teachers play important role in encouraging an active teaching and learning process where it's focused on student-centered. To improve the current teaching and learning process, teachers should find the appropriate learning model for each material, make innovative learning strategy and draw students' attention. Therefore, teachers need to find a learning model which changes the current process from teacher-centered approach to studentcentered. One of the suggested innovative learning strategies for increasing students' participation in classroom is cognitive conflict learning model.

Cognitive conflict based learning model is designed and developed from a problem-based learning model proposed by [5] as a basic model, and combined with cognitive conflict strategy. The combination between these problembased learning models is expected to overcome the students' problem in understanding the concepts by involving the process of deep thinking or high-level thinking.

In improving critical thinking skill, it is widely known that there are several important elements. Each student has a different method in solving problem and various learning style [6]. Each student will choose the favorable way in processing and organizing information in response to their learning environment.

In cognitive style, there are different ways to see, recognize, and organize information. One of the variables in learning conditions in the classroom that need to be considered by the teacher is cognitive style Joyce [7]. Cognitive style is needed to design or modify learning material, learning goals, and learning methods.

Cognitive style is part of the learning style. Cognitive style is part of the learning style that describes the habit of behaving that is relatively fixed in a person in receiving, thinking, solving problems, and in storing information

Cognitive style is a process or controlled action that arises in students in determining students' conscious activities in organizing, managing, receiving, and sharing the information and also determining students' behavior.

Thus, cognitive style can be said as a way for students to capture process and execute the information in a consistent action or behavior in teaching and learning process.

Cognitive style can be distinguished into two: the field dependent (FD) and field independent (FI). Each of these cognitive styles also has its own characteristics that differentiate them [10]. Individual in FD is a type of individual who thinks globally and tends to be passive, on the other hand, individual in FI is a type of person who understands and processes information analytically [11]. The character of students and problem-solving in processing information based on this cognitive style will be different for each student.

The dimension of cognitive style that specifically needs to be considered in learning, especially mathematics learning, is cognitive area which classified into different learning field. They are dependent and independent 
cognitive style. Teachers need to choose a teaching strategy that matches the students' cognitive, so that learning will achieve optimal result. Cognitive style is the attitude or way of an individual in organizing information and experience that determine how people accept, remember, think and solve problems. Cognitive style is related to the process that students use to organize, receive and send information and behavior. There are two types of cognitive styles: field independence (FI) and field dependence (FD).

There are three main phases in learning using cognitive conflict strategies. First, we can identify student's misconceptions. Second, we can confront students' ideas (preconceptions) with scientific conceptions. Third, we can change the misconceptions into scientific conceptions [12]. The preconceptions are student's pure initial knowledge or nature knowledge which brought to schools environment. It is clearly related to students' cognitive style. This means, the best learning model will be cognitive conflict strategy.

Cognitive style is the way how students arrange and process information and experiences originated from their environments [13]. Student as a unique individual certainly has different cognitive style from their peers. The cognitive style possessed by students will have a positive impact or influence if the appropriate supporting environment and conditions are provided, so students can learn optimally.

Based on explanation above, it is expected that cognitive conflict based learning model can facilitate students with different cognitive styles to develop students' mathematical critical thinking skill. Hence, the title of this research is The Effect of Cognitive Conflict Learning Model Toward VIII Grade Students' Critical Thinking Skills in terms of Cognitive Style in Bukittinggi.

\section{Methods:-}

The effect of cognitive conflict-based learning model on students' mathematical critical thinking skills is observed through experimental research method. The experimental method is used to find the effect of certain treatments on other things under controlled conditions [14]. The research design used was non-equivalent control post-only group design.

Table 1:-Non-Equivalent Control Posttest-Only Group Design

\begin{tabular}{|c|c|c|}
\hline Group & Treatment & Post-test \\
\hline Experimental & $\mathrm{X}$ & $\mathrm{T}$ \\
\hline Control & $\mathrm{O}$ & $\mathrm{T}$ \\
\hline
\end{tabular}

There are two groups in this research, control and experimental group. The experimental group was taught by using cognitive conflict based learning model, while the control group used conventional learning model. At the end of learning process, the two groups were given the same test of critical thinking skill.

The research sample population was junior high school students in Bukittinggi. Eight public junior high schools in Bukittinggi are divided into three levels: upper, intermediate and lower level school as sub-populations. This allocation is based on the results of Bukittinggi National Examination in 2017/2018. The selection of this subpopulation was determined with stratified sampling. Each chosen school represents the level. It means that the researcher only needs one junior high school per level. Furthermore, the groups are 1 class for control group and 1 class for experimental group. In summary, there are six classes that will be observed.

The instruments used to collect data in this research were tests of critical thinking skill and GEFT (Group Embedded Figure Test). Students' cognitive style is determined in GEFT. The test subject is asked to find a simple image on 18 complex images in the given time (12 minutes). Based on the number of correct answers, the score in GEFT starts from 0 - 18.

The critical thinking ability test consists of four questions in the form of essay about statistical materials, four questions for each of the following four indicators, 1) Understanding the problems, indicated by writing down the information given and questions asked (interpreting), 2) Identifying relationships between statements, questions, and concepts given in the questions which shown by writing mathematical models correctly and giving precise explanations (analysis), 3) Using the right strategies in solving problems, do the calculation completely and correctly (evaluate), 4) Drawing conclusion (inference). 


\section{Discussion:-}

The score for mathematical critical thinking and cognitive style are obtained at the end of the research. The score distribution is presented in appendix. The results of critical thinking skill test are shown in the following table 2.

Table 2:-The results of mathematical critical thinking skill per school level.

\begin{tabular}{|c|c|c|c|c|c|c|}
\hline Schools Level & $\begin{array}{l}\text { Math } \\
\text { Skill }\end{array}$ & $\mathrm{N}$ & $\begin{array}{l}\text { Max- } \\
\text { value }\end{array}$ & $\begin{array}{l}\text { Min- } \\
\text { value }\end{array}$ & Average & $\begin{array}{c}\text { Standard } \\
\text { Deviation }\end{array}$ \\
\hline \multirow[t]{2}{*}{ Upper } & Experimental & 32 & 95 & 30 & 67,19 & 21,65 \\
\hline & Control & 32 & 56 & 20 & 35,31 & 8,83 \\
\hline \multirow[t]{2}{*}{ Intermediate } & Experimental & 26 & 94 & 31 & 58,46 & 15,60 \\
\hline & Control & 21 & 75 & 36 & 53,86 & 13,59 \\
\hline \multirow[t]{2}{*}{ Lower } & Experimental & 20 & 80 & 16 & 41,80 & 20,23 \\
\hline & Control & 27 & 86 & 6 & 37,37 & 24,88 \\
\hline
\end{tabular}

In table 2, it can be observed that the experimental classes have higher dominating average than the control classes in critical thinking skill for upper, intermediate and lower level. The standard deviation of the experimental classes are still higher compared to all level of control classes, this indicates that the test scores of the control classes critical thinking skill are relatively insignificant to experimental classes. The low score of standard deviation in the experimental class compared to the standard deviation of the control class indicates that the test scores of the experimental class critical thinking abilities are more likely similar compared to the control classes for lower level schools.

Here are the comparisons of average test result in mathematical critical thinking which implemented in every school level:

After collecting data in students' cognitive style, it was found that there were 26 field-independent students, and 6 field-dependent (FD) students. Meanwhile in the control class, there were 16 field-independent (FI) students, and 16 students were field dependent (FD). Based on this data, the critical thinking ability test results in terms of different cognitive style were obtained which can be seen in Table 3

Table 3:-Students' test results in terms of different cognitive style

\begin{tabular}{|c|c|c|c|c|c|c|c|}
\hline School Levels & Sample & $\begin{array}{c}\text { Cognitive } \\
\text { Style }\end{array}$ & $\mathrm{N}$ & $\begin{array}{l}\text { Max- } \\
\text { value }\end{array}$ & $\begin{array}{l}\text { Min- } \\
\text { value }\end{array}$ & Average & $\begin{array}{c}\text { Standard } \\
\text { Deviation }\end{array}$ \\
\hline \multirow{4}{*}{ Upper } & \multirow{2}{*}{ Experimental } & FD & 6 & 83 & 34 & 54,83 & 19,13 \\
\hline & & FI & 26 & 95 & 30 & 70,04 & 21,51 \\
\hline & \multirow{2}{*}{ Control } & FD & 16 & 56 & 25 & 35,13 & 8,06 \\
\hline & & FI & 16 & 52 & 20 & 35,50 & 9,79 \\
\hline \multirow{4}{*}{ Intermediate } & \multirow{2}{*}{ Experimental } & FD & 10 & 69 & 31 & 52,70 & 13,67 \\
\hline & & FI & 18 & 94 & 33 & 60,17 & 16,49 \\
\hline & \multirow{2}{*}{ Control } & FD & 8 & 75 & 38 & 61,75 & 14,35 \\
\hline & & FI & 13 & 73 & 36 & 49,00 & 10,99 \\
\hline \multirow{4}{*}{ Lower } & \multirow{2}{*}{ Experimental } & FD & 9 & 80 & 16 & 44,56 & 23,77 \\
\hline & & FI & 13 & 77 & 20 & 41,69 & 17,72 \\
\hline & \multirow{2}{*}{ Control } & FD & 19 & 86 & 9 & 38,42 & 20,96 \\
\hline & & FI & 8 & 78 & 6 & 34,88 & 34,03 \\
\hline
\end{tabular}

In Table 3, the test result of critical thinking skill in the upper level experimental class alongside the FD and FI cognitive styles are higher than the average score in control class. Meanwhile in the intermediate level, the students' average test score in critical thinking skills of FD students in the experimental class were lower than the FD students in the control class. The next obtained data, the average critical thinking test score for FI students in experimental class are higher than FI students in control class. The last level, the average critical thinking test score for both FD and FI students in experimental class are higher than FD and FI students in control class.

After conducting a test to see how the interaction and the effect of cognitive style and learning model toward critical thinking skill, the result showed that there is no interaction between intermediate and lower level school. It means 
that both learning model and cognitive style are not affecting critical thinking skill on upper and lower level students.

Following the test result provided above about the interaction between cognitive style and learning models toward critical thinking skill in intermediate level students, the results are positively good. It means that both the learning model and cognitive style affect students' critical thinking skill in intermediate level.

The first examined indicator of mathematical critical thinking skill is to understanding the problems which indicated by writing given information and asking questions correctly (interpreting). The average test results in the first indicator in the experimental class were higher than the control class for all school levels. These shows the majority students in experimental class who implement PBKK model are able to interpret the questions accurately.

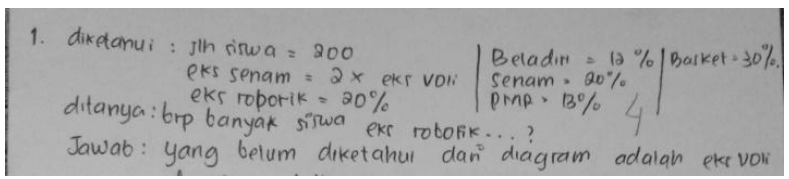

Figure 1:-An example of Experimental Student's answer sheet.

Based on the Figure, student's answer sheet, the writer concludes that the students are able to interpret the question completely and accurately. He has written the precise given information and asked question. So, he gained 4 score for that answer.

On the opposite, the most dominant majority answers in control class students in interpreting the question is shown in this Figure 2 below

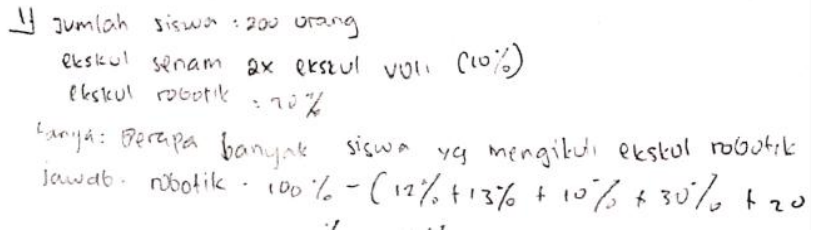

Figure 2:-An example of Control class student's answer sheet.

The contrast difference level happened because the experimental class students are facilitated to develop their critical thinking skill by interpreting the questions accurately and following systematic steps. Occasionally, there are still control class students who ask whether they should interpret the problem. Even though it is clearly must be written so that they can answer systematically. Meanwhile, in experimental class, students are get used to solve the problem clearly and accurately.

As for the second indicator, identifying relationships between statements, questions, and concepts given in the questions which shown by writing mathematical models correctly and giving precise explanations (analysis), the percentage results are $57.03 \%$ in the experimental classes while only $24.21 \%$ in the control classes. It shows that almost all experimental students answered perfectly compared to those in control class. It is okay to say that experimental class students are able to identify the relationships between statements, questions, and concepts given in the questions which shown by writing mathematical models correctly and give precise explanation.

The third indicator test results are $68.75 \%$ for the experimental classes while $50 \%$ for the control class. The percentage clearly shows that students in the experimental class are better than control class students in evaluating, choosing the right strategy and calculating the math problem accurately.

The last indicator, fourth indicator, test results are $75 \%$ for the experimental classes and $44.35 \%$ for control class. It means the experimental class students are good at answering the math problem with complete answer rather than control class students. It means most of them can draw a correct conclusion. 


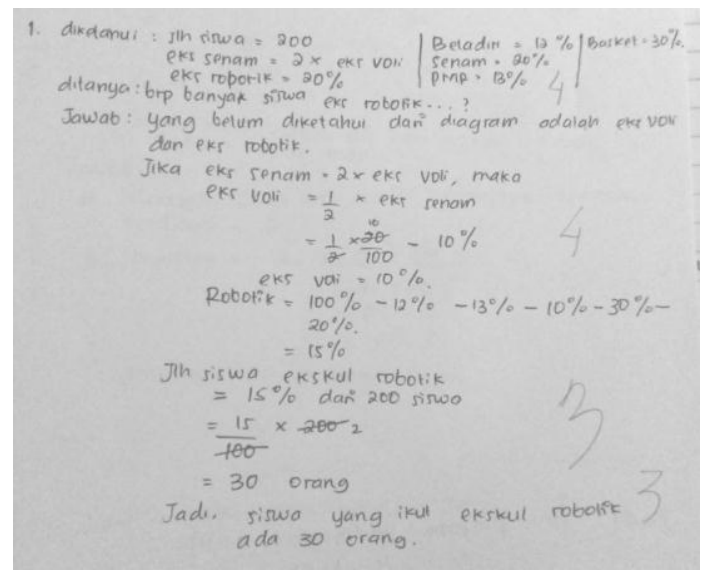

Figure 3:-An experimental student's answer sheet.

At the first glance, the answer in Figure 3 looks perfect, but if you take a closer look in each indicator, the answer is not fully completed. There is still a critical thinking skill that is required in calculating the answers, so the score is not perfect. In figure 3, the first indicator score is 4 , the highest score, where student is able to understand the problem indicated by writing given information and asking correctly. For second indicator, the score is also the highest where he made a mathematical model of the question given and giving the explanation correctly and completely. The third indicator score is 3 because he used the right strategy in solving the problem, yet there was an incomplete calculation for the fourth indicator, the score is also 3 because he draws incomplete conclusion.

In the first hypothesis, it is smaller than the significant level $(\alpha=0,05)$, rejected and accepted. It means that there are differences in the average results test of mathematical critical thinking skill in the experimental class and the control class at the upper level. Therefore, "the critical thinking skill of grade VIII junior high school students in Bukittinggi with PBKK learning model is different from the mathematical critical thinking skill from the students who use conventional models in upper level.

In the 5th and 9th hypotheses are bigger than the significant level $(\alpha=0,05)$, rejected and accepted. It means that there is no difference on the average results of the mathematical critical thinking ability in the experimental class and control class students in intermediate and lower level. It can be concluded that "the critical thinking skill of grade VIII junior high school students in Bukittinggi with PBKK model has similar result with conventional students in intermediate and lower level.

In second hypothesis, it is smaller than the significant level $(\alpha=0,05)$, rejected and accepted. It implied that there are contrast average test results in mathematical critical thinking skill of FD students in experimental class and control class students in upper level. It is okay to say that "the critical thinking skill of FD student with PBKK model in grade VIII in Bukittingi is different with FD students who still use conventional model in upper level".

In the 6th and 10th hypotheses 6 , it is bigger than the significant level $(\alpha=0,05)$, rejected and accepted. It means that there is no difference in the test average results of the mathematical critical thinking skill for both FD students in experimental classes and control classes in intermediate and lower level. It is implied that "the critical thinking skill of FD student with PBKK model in grade VIII in Bukittingi is similar to FD students with conventional model in intermediate and lower level.

In the 3rd and 7th hypotheses, it is smaller than the significant level $(\alpha=0,05)$, rejected and accepted. It means that there are differences in the test average results in mathematical critical thinking ability for FI students in experimental classes and control classes at upper level and intermediate level. It can be inferred that the critical thinking skill of FI students with PBKK model in grade VIII in Bukittingi is different with FI students with conventional model in upper and intermediate level.

In the 11th hypothesis, it is greater than the significant level $(\alpha=0,05)$, rejected and accepted. This means that there is no difference in the test average results in mathematical critical thinking ability for FI students in 
experimental classes and control classes in lower level. It can be inferred that the critical thinking skill of FI students with PBKK model in grade VIII in Bukittingi is similar with FI students with conventional model in lower level.

In the 4th and 12th hypotheses, both the effect of the learning model and cognitive style lines on critical thinking abilities do not intersect, rejected and accepted. It means there is no interaction between learning models and cognitive styles toward students' critical thinking skills in both upper and lower level.

In hypothesis 8 , it can be seen that both the effect of the learning model and cognitive style factors in critical thinking skill have intersecting lines, rejected and accepted. It means that there is an interaction between learning models and cognitive styles toward students' critical thinking skills in intermediate level.

Here are several differences happened for each hypothesis in students' answer sheet:

\section{1st Hypothesis}

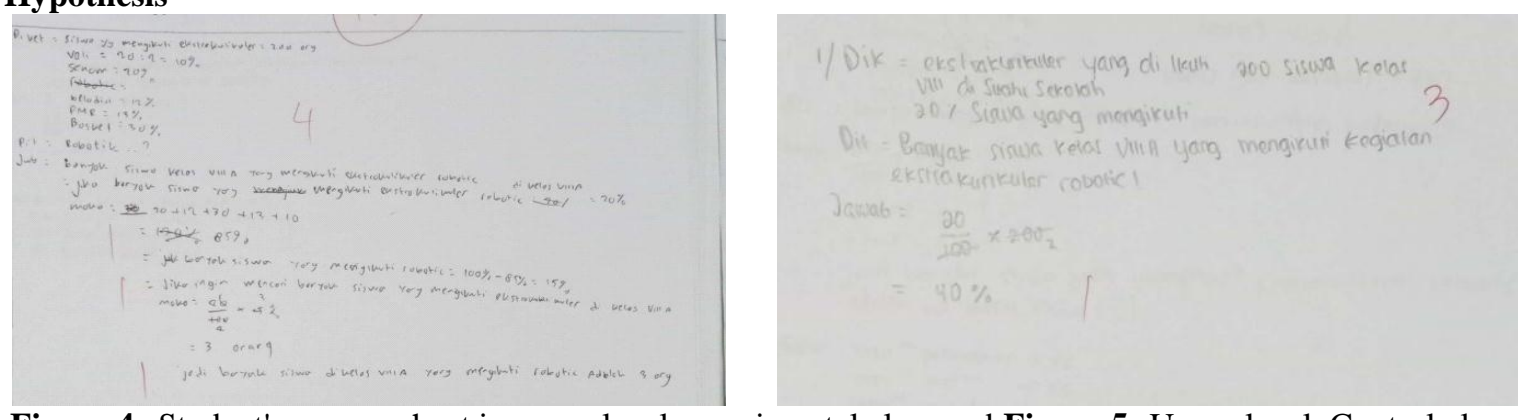

Figure 4:-Student's answer sheet in upper level experimental class and Figure 5:-Upper level, Control class.

In Figure 4, only one of the answers got 4 score. The rests indicators are bad. In Figure 5, the student's answer sheet of control class got 3 score for the first indicator, no score for 2 nd indicator, 1 score for 3rd indicator and no score for 4th indicator. From the Figure 4 and 5, we can conclude that there is a big difference between experimental class and control class in upper level. It means the rest hypotheses will follow the same procedure. Here is the 2nd hypothesis.
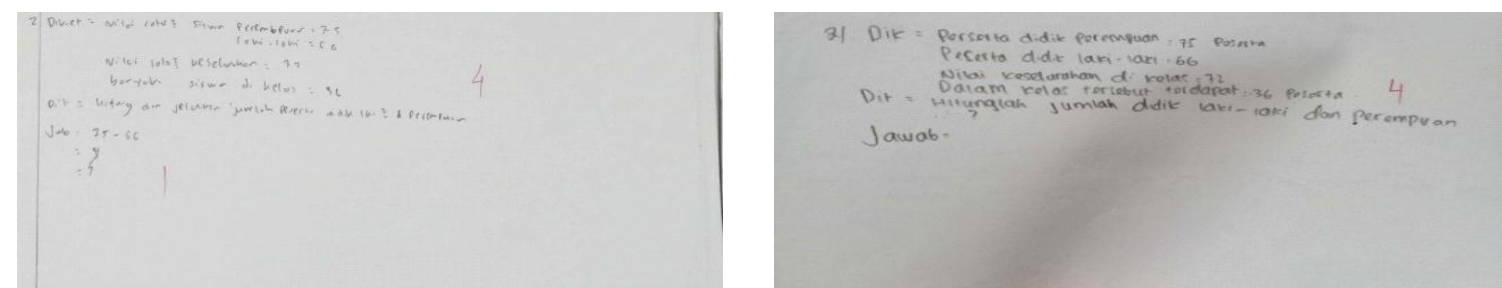

Figure 6:-FD Answer sheet in Upper level experimental class. And Figure 7:-FD Answer sheet in Upper level Control class.

Based on Figure 6 and 7, FD students in upper level experimental class is different with FD students in upper level control class. For the 3rd hypothesis as follow:
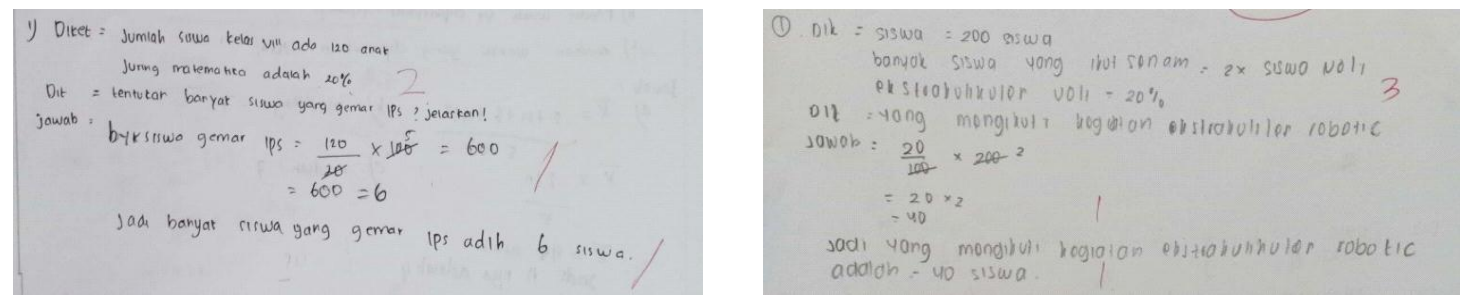

Figure 8:-FI Answer sheet in upper level experimental class and Figure 9:-FI Answer sheet in upper level control class.

Based on figure 8 and figure 9, it can be concluded that FI students in upper level experimental class is different from FI students in upper level control class. 
Next, for the 4th hypothesis:
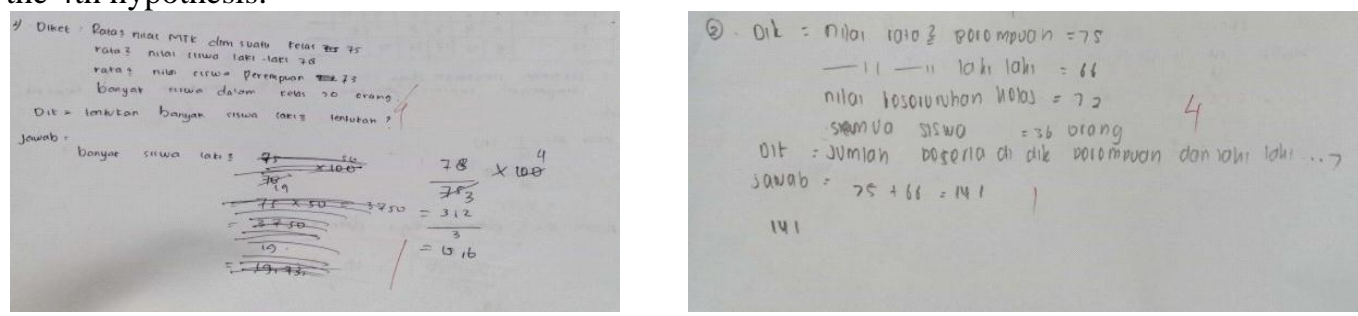

Figure 10:-FD Answer sheet in upper level experimental class. And Figure 11:-FI Answer sheet in upper level control class.

Comparing the result on figure 10 and 11, it can be inferred that both FI student in upper level experimental class and FI student in upper level control class do not master the solution for the math problem above. It means the same thing will be applied until the 12th hypothesis.

\section{Here is the 5th hypothesis:}
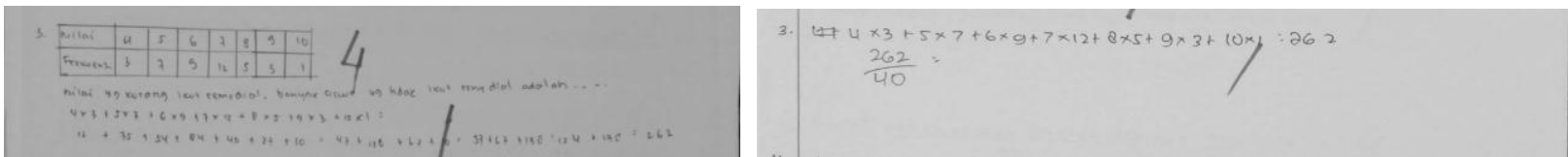

Figure 12:-Intermediate level, experimental class and Figure 13:-Intermediate level, control class.

Based on figure 12 and 13, it shows that there is clearly difference in intermediate level in experimental class and control class.

Here is the 6th hypothesis:
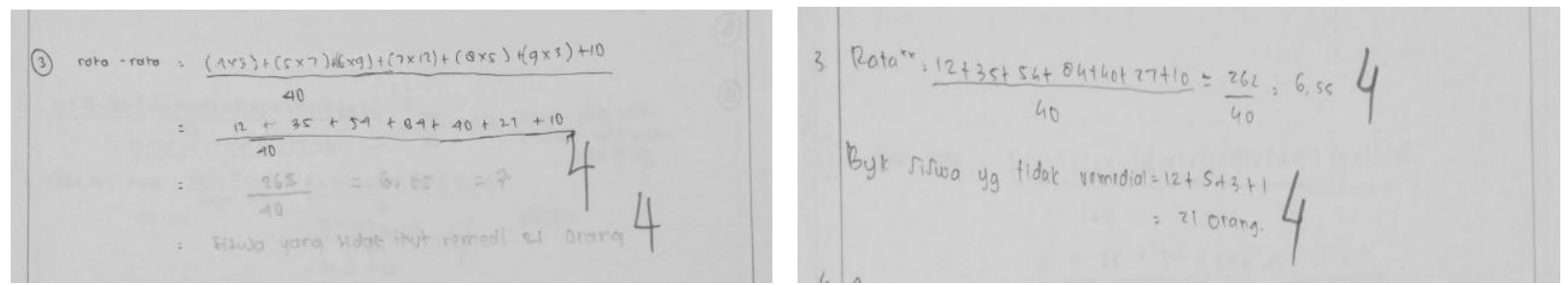

Figure 14:-Intermediate level, FD experimental class and Figure 15:-Intermediate level FD control class.

Based on figure 14 and 15, it shows that there is slightly difference for FD students in intermediate level in experimental class and control class.

Here is the 7th hypothesis:
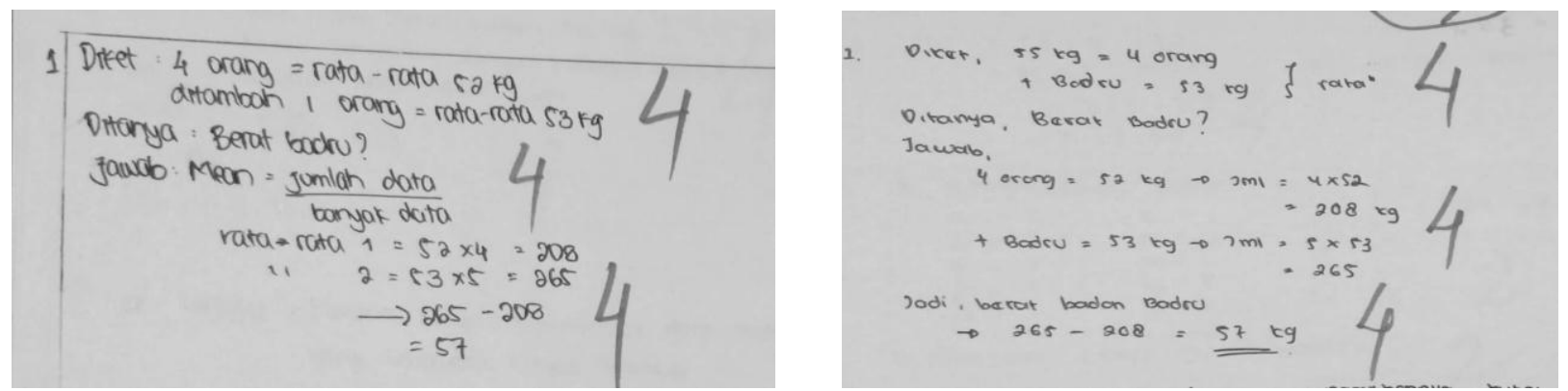

Figure 16 and 17:-Intermediate level, FI experimental class and Intermediate level, FI control class.

Based on figure 16 and 17, it shows that there is different answer for F1 students in intermediate level in experimental class and control class. 
This is the 8th hypothesis:
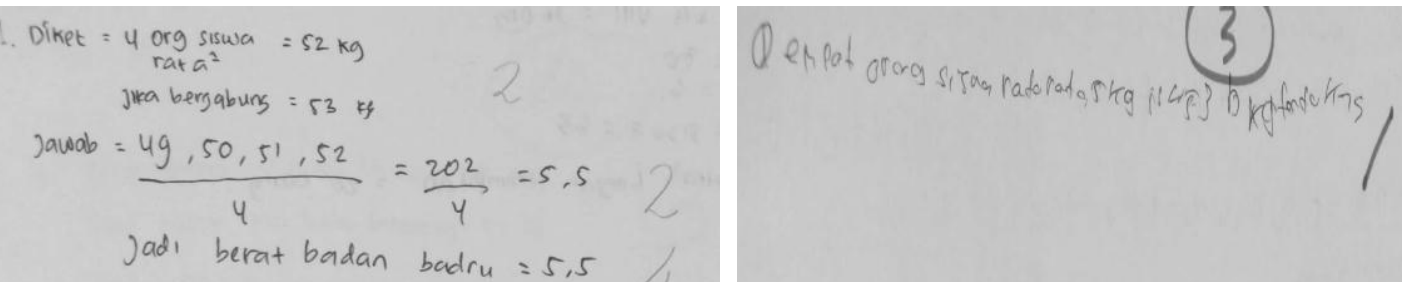

Figure 18:-Intermediate level, FI experimental class and Figure 19:-Intermediate level, FD control class

Based on figure 18 and 19, it shows different answer.

Here is the 9th hypothesis:
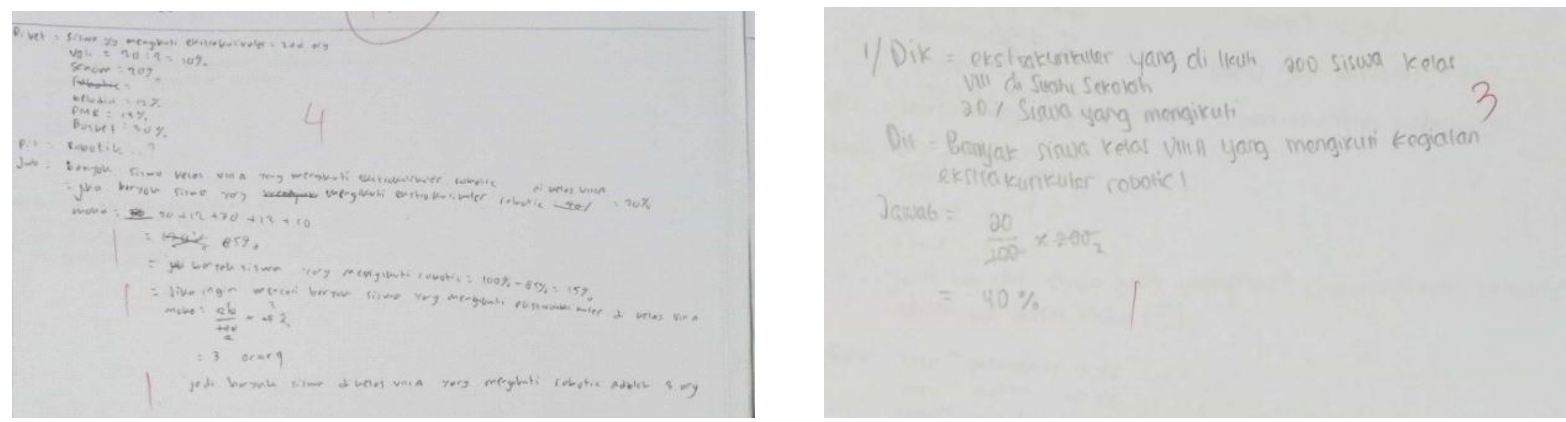

Figure 20 Lower levels, experimental class. Figure 21 Lower levels, control class.

Comparing figure 20 and 21, it can be concluded that experimental class and group class has difference.

Here the 10th hypothesis:

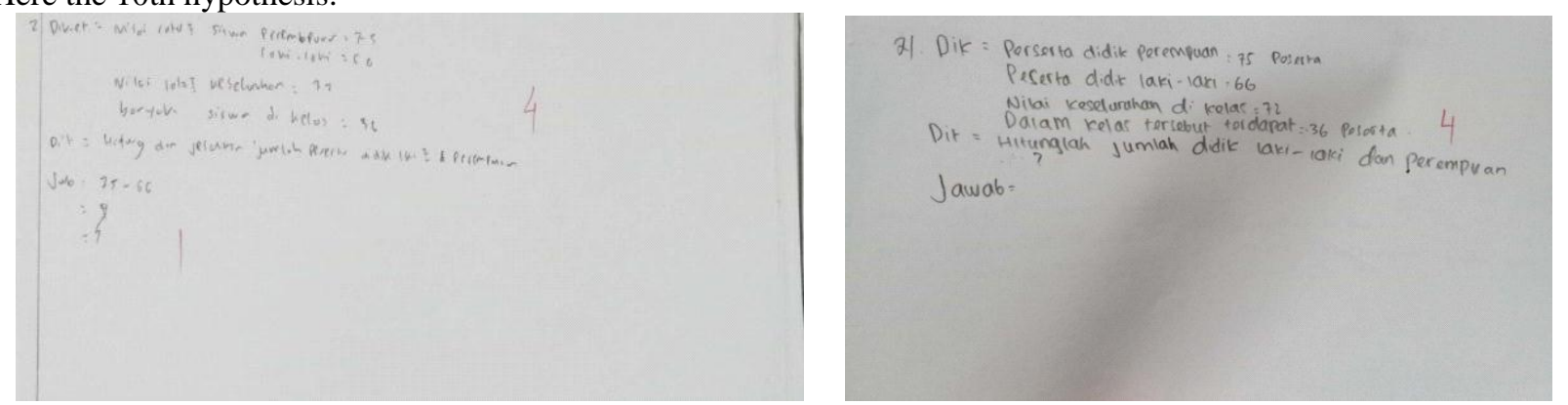

Figure 22:-Lower level, FD experimental class and Figure 23:-Lower level, FD control class.

Based on figure 22 and figure 23, it can be concluded that FD student from experimental class is different from FI student from control class in lower level.

Next, for the 11th hypothesis:
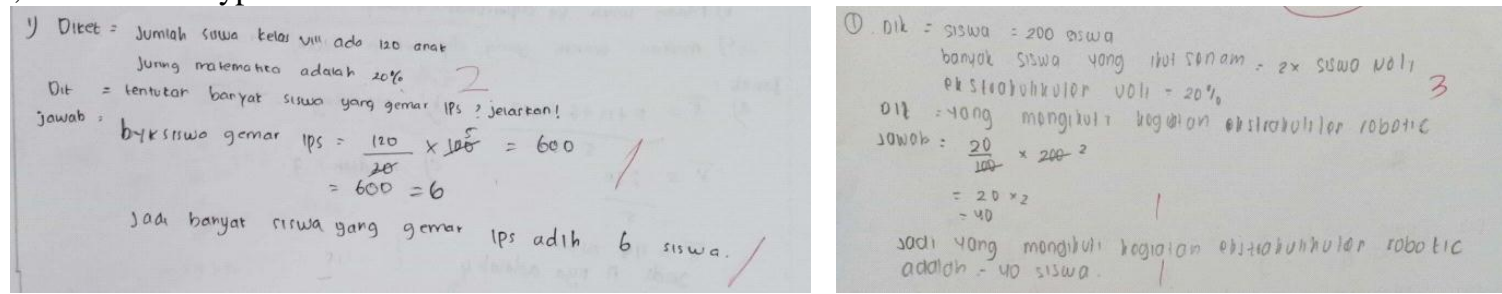

Figure 24:-Lower level, FD experimental class and Figure 25:-Lower level, FI control class. 
Based on figure 24 and figure 25, it can be concluded that FI student from experimental class is different from FI student from control class in lower level.

The 12th hypothesis as follow:
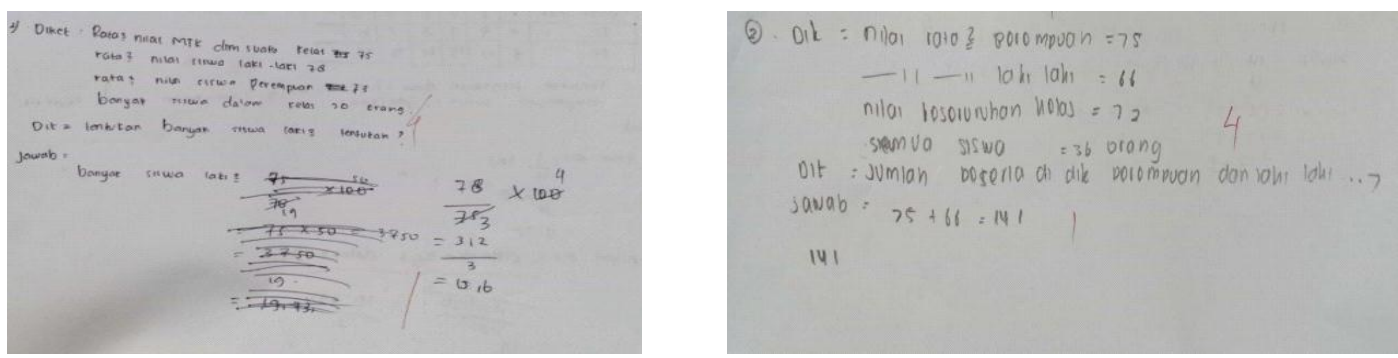

Figure 26:-Lower level, FD experimental class and Figure 27:-Lower level, FI control class.

Based on figure 26 and figure 27, it can be concluded that FD student from experimental class is different from FI student from control class in lower level.

Based on the upcoming research analysis finding can be inferred that PBKK learning model is better for FI students and conventional learning model is suitable for FD students in order to enhance students' critical thinking skill.

\section{Conclusion:-}

Based on the research findings and discussion, it can be concluded that students' critical thinking skill with cognitive style learning model is better than students who are using conventional learning mode. It means cognitive conflict learning model gave good impact toward critical thinking skill in upper level.

There is a quite significant students' difference in critical thinking skill between cognitive field-dependent students with PBKK model and field-dependent students with conventional model in upper level. It means that fielddependent students' critical thinking skill using PBKK model are different from field-dependent students using conventional model in upper level.

There is a significant difference in students' critical thinking skill between cognitive field-independent students with PBKK model and field-dependent students with conventional model in intermediate level. Therefore, fieldindependent students' mathematical critical thinking skill using PBKK models are different from field-independent students using conventional model in upper and intermediate levels.

There is an interaction between learning models and cognitive styles in influencing students' critical thinking skills in intermediate level. Cognitive conflict learning model is more suitable for FI students in intermediate level to influence their critical thinking skill.

\section{References:-}

1. Krulik, S.1980. Problem Solving in School Mathematics. NCTM

2. Zubaidah,S. 2015. Asesmen Berpikir Kritis Terintegrasi Tes Essay. (Online) (https://www.researchgate.net/publication/322315188_Asesmen_Berpikir_Kritis_Terintegrasi_Tes_Essay), diakses tanggal 19 Desember 2018.

3. Permendikbud. Nomor 22 Tahun 2016. Standar Proses Pendidikan Dasar dan Menengah. Jakarta : BSNP

4. Ismaimuza, D. 2010. "Kemampuan berpikir kritis dan kreatif matematis siswa SMP melalui pembelajaran berbasis masalah dengan strategi konflik kognitif”. SPS UPI. Disertasi tidak diterbitkan.

5. Mufit, Fatni. 2018. Model Pembelajaran Berbasis Konflik Kognitif(Pbkk) Untuk Meningkatkan Pemahaman Konsep dan Meremediasi Miskonsepsi. Padang. Universitas Negeri Padang.

6. Slavin, R.E. 2008. Educational Psychology: Theory and Practice. Terjemahan Marianto Samosir. Jakarta: PT Indeks.

7. Hamzah B. Uno. 2006. Orientasi Baru dalam Psikologi Pembelajaran. Jakarta: Bumi Aksara.

8. Jamess W. Keefe. 1987. Learning style Theory \& Practice. Virginia: National Association of Secondary School Principals. 
9. Bassey, Sam. W \& Umoren, Grace. 2009. Cognitive Styles, Secondary School Students' Attitude and Academic Performance in Chemistry in Akwa Ibom State-Nigeria. www.gbcse.tifr.res.in/episteme/episteme-2/eproceedings/bassey. [diakses 29 Oktober 2018]

10. Witkin, H., Moore, C., Goodenough, D., \& Cox, P. (1977). Field-dependent and field Independent cognitive styles and their educational implications. Review of Educational Research, 47(1), 1-64.

11. Ghinea, G \& Chen, SY. (Ed). 2006. Digital Multimedia Perception and Design. London: Idea Group.

12. Sadia, I Wayan. 2014. Model-Model Pembelajaran Sains Konstruktivistik. Jogyakarta: Graha Ilmu.

13. Amrina, Z. 2004. " Hubungan antara Gaya Kognitif Dengan Hasil Belajar Matematika Siswa Kelas II SMU Negeri di Kota Padang”. Jurnal Pembelajaran 27 (1).57-69.

14. Sugiyono. 2010. Metode Penelitian Pendidikan Pendekatan Kuantitatif, Kualitatif, dan R \&D. Bandung: Alfabeta. 